\title{
Regional co-ordinator for haemophilia in domiciliary practice
}

\author{
B T COLVIN, CHERYL ASTON, GILLIAN DAVIS, G C JENKINS, KATHARINE M DORMANDY
}

British Medical fournal, 1977, 2, 814-815

\section{Summary}

The North-east Thames Region has appointed a nursing sister to co-ordinate the organisation of care for haemophiliacs in the region. As a result of the appointment, facilities for home treatment have expanded rapidly. Several associate centres providing care to haemophiliacs have been set up around the region in addition to the four main haemophilia centres, which are all in the southwest corner of the region. As well as providing support and supervision of patients on home treatment, the co-ordinator helps to place haemophiliac children in suitable schools, maintains the regional register of haemophiliacs, and has a more general role in ensuring that services are available where they are needed throughout the region.

\section{Introduction}

In 1974 the DHSS sent the first draft of its circular on haemophilia $^{1}$ to health authorities for comment. At the same time the newly formed North-east Thames Regional Health Authority, in appraising the immediate requirements of the region, became aware of the need to expand facilities for home treatment of patients with severe haemophilia. The home treatment already practised on a limited scale had been an acknowledged success and clotting factor concentrates were becoming increasingly available. The DHSS circular laid down criteria for designating haemophilia centres and asked regional health authorities to review their treatment centres.

To ascertain how best to meet these requirements the chairman of the Association of Haematologists in the region convened a working party to consider the region's policy for organising haemophilia care and, especially, expanding home treatment facilities. Every haematologist in the region was invited to attend the first meeting, held in October 1975. Representatives attended from the region's four haemophilia centres (the Royal Free Hospital, the London Hospital, the Hospital for Sick Children, and University College Hospital) and from three hospitals which also cared for several haemophiliacs (Harlow, Colchester, and Orsett).

London Hospital Medical College, London E1 2AD

B T COLVIN, MRCP, MRCPATH, lecturer in haematology

G C JENKINS, PHD, FRCPATH, professor of haematology and director of haemophilia centre

North-east Thames Regional Blood Transfusion Centre, Brentwood, Essex

CHERYL ASTON, BSC, SRN, formerly co-ordinator

GILLIAN DAVIS, SRN, co-ordinator for haemophilia in domiciliary practice

Department of Haematology, Royal Free Hospital, London NW3 2QG

KATHARINE M DORMANDY, MD, FRCP, reader in haematology and director of haemophilia centre

\begin{abstract}
Aims
The working party recognised the need to provide a link between hospital and community care. As a first step all the haemophiliacs in the region would have to be identified. This information was needed for the National Haemophilia Register, but the working party decided also to compile a regional register, which would be kept at the regional blood transfusion centre. The working party also agreed that it was essential to have as a regional co-ordinator a nursing sister trained in haemophilia care.

So that the work could start without delay the Haemophilia Society generously funded the co-ordinator's post for 14 months on an experimental basis. A suitably trained nursing sister who had already worked for two years at the Royal Free Hospital haemophilia centre was appointed to the post, which was established at Salmon grade 6. She was based at the blood transfusion centre at Brentwood because of its central position.
\end{abstract}

\section{The co-ordinator's task}

The co-ordinator's initial task was to visit the haemophilia centres to identify patients, plot their distribution, note clinical and laboratory data, and verify details such as home addresses, general practitioners, and current occupations. Details of the services offered by the different centres-for example, facilities for surgery, rheumatological and orthopaedic supervision, and genetic counselling-were also obtained.

Although some patients were already receiving home treatment, the presence of a co-ordinator enabled the directors of haemophilia centres to expand the programme rapidly. Patients were selected for home treatment by the directors, and then visited at home by the co-ordinator, who confirmed their general suitability for the scheme. The points she looked for included an adequate home environment, the willingness of the patient or a relative to learn venepuncture techniques, the presence of a telephone, the availability of suitable cold storage space, agreement of the general practitioner, and the ability to keep simple records. Patients and their relatives received their initial training in venepuncture techniques at a haemophilia

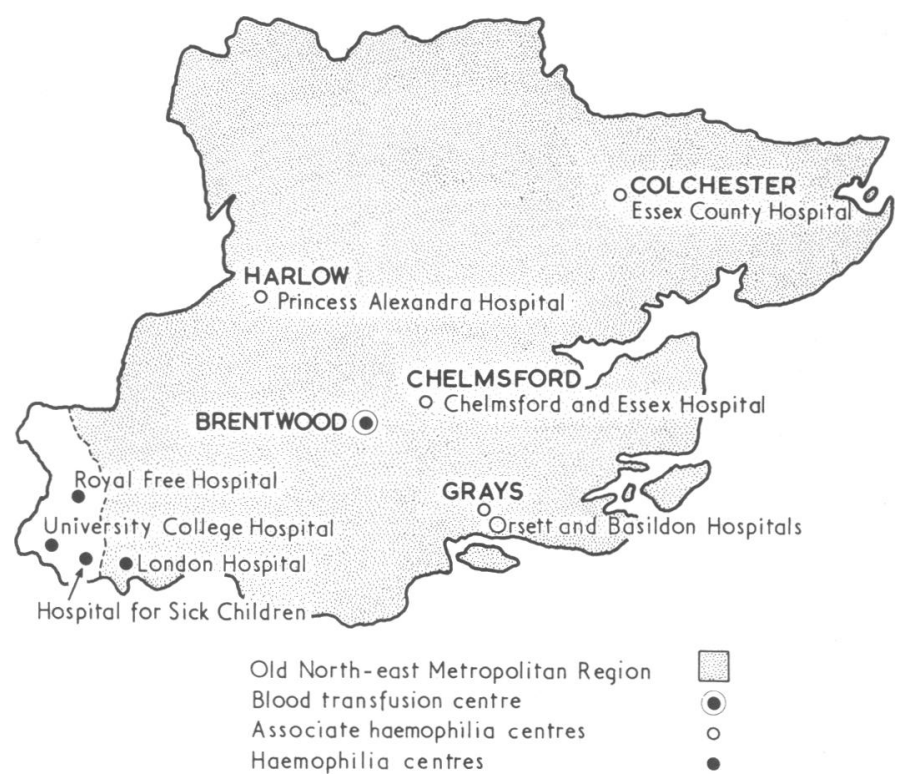

Haemophilia centres and associate centres in North-east Thames Region. 
centre but the co-ordinator often continued supervision in their homes.

Once home treatment had begun the co-ordinator visited the patients regularly to identify any problems and, if necessary, arranged to transport supplies and remove waste materials. The directors of the haemophilia centres consequently needed to see patients at only three-monthly intervals and the patients did not feel isolated. The co-ordinator could also play an important part in assessing the requirements for factors VIII and IX throughout the region, especially in relation to home treatment.

Occasionally the directors saw patients in their local hospitals or at home, as some patients found it difficult to get to the main haemophilia centres, which are all in the extreme south-west of the region (see figure).

As part of the working party's plan for haemophilia care, four associate centres have now been set up at Colchester, Harlow, Chelmsford, and Orsett with the help of the co-ordinator.

The co-ordinator is also in an ideal position to visit schools to discuss the problems that face teachers and pupils when a haemophilic child joins them. She is often able to help in the consultations leading to placing children in suitable schools.

\section{Details of patients}

The total number of patients identified in the region so far is 412 . Of these 279 have haemophilia A (factor VIII deficiency) and 52 have haemophilia B (factor IX deficiency; Christmas disease). There are 81 known patients with von Willebrand's disease. The severity of haemophilia among these patients is shown in table I.

TABLE I-Severity of clotting disorder

\begin{tabular}{r|c|c|c|c}
\hline Levels of factors $(\mathrm{U} \mathrm{ml}):$ & $<0.02$ & $0 \cdot 02-0 \cdot 10$ & $>0 \cdot 10$ & Unknown \\
\cline { 2 - 4 } $\begin{array}{c}\text { Patients with haemophilia A } \\
\text { Patients with haemophilia B }\end{array}$ & $\begin{array}{c}90 \\
13\end{array}$ & $\begin{array}{c}107 \\
18\end{array}$ & $\begin{array}{c}75 \\
18\end{array}$ & $\begin{array}{c}7 \\
3\end{array}$ \\
\hline
\end{tabular}

TABL.E II-Numbers of patients cared for at each centre and treated at home according to type of haemophilia and preparation

\begin{tabular}{|c|c|c|c|c|}
\hline & \multicolumn{4}{|c|}{ Haemophilia } \\
\hline & $\begin{array}{c}\text { A } \\
\text { (factor VIII } \\
\text { cryoprecipitate) }\end{array}$ & $\begin{array}{l}\text { A } \\
\text { (factor VIII } \\
\text { concentrate) }\end{array}$ & $\begin{array}{c}\text { B } \\
\text { (factor IX } \\
\text { concentrate) }\end{array}$ & Total \\
\hline $\begin{array}{l}\text { Royal Free Hospital } \\
\text { London Hospital } \\
\text { Hospital for Sick } \\
\text { Children }\end{array}$ & $\begin{array}{r}11 \\
3 \\
0 \\
\end{array}$ & $\begin{array}{l}8 \\
8 \\
5\end{array}$ & $\begin{array}{l}2 \\
2 \\
1\end{array}$ & $\begin{array}{r}21 \\
13 \\
6\end{array}$ \\
\hline $\begin{array}{l}\text { University College } \\
\text { Hospital } \\
\text { Hospitals outside region }\end{array}$ & $\begin{array}{l}1 \\
0\end{array}$ & $\begin{array}{l}1 \\
3\end{array}$ & $\begin{array}{l}0 \\
2\end{array}$ & $\begin{array}{l}2 \\
5\end{array}$ \\
\hline Total & 15 & 25 & 7 & 47 \\
\hline
\end{tabular}

In addition to their 145 patients in the North-east Thames Region, the Royal Free Hospital has substantial commitments to the other three Thames regions. The Hospital for Sick Children, which cares for 33 of the region's haemophiliacs, also has extensive external commitments. Of the remaining 234 haemophiliacs living in the region 190 are cared for at the London Hospital, 27 at University College Hospital, and 17 at hospitals in other regions. Table II shows the number of patients receiving home treatment. An additional 18 unregistered patients, who are not included in these figures, have been identified.

So far the co-ordinator has visited nine schools and eight general practitioners.

\section{Discussion}

There has been increasing interest recently in making the best use of nursing staff, 2 and haemophilia centres have relied heavily on nursing skills. Most nursing work has been within hospitals but nurses have also visited patients at home. For example, a State-registered nurse has successfully provided a domiciliary service for the administration of plasma fractions to haemophiliacs in the Southampton area. ${ }^{3}$

The post of co-ordinator of domiciliary care for haemophiliacs has wider terms of reference and has proved extremely valuable. After only 10 weeks worthwhile results were obtained, ${ }^{4}$ and the region has now taken over responsibility for the post from the Haemophilia Society.

Compiling the regional register of haemophiliacs was a laborious task, and its maintenance will require continued effort, but the register does provide an accurate record of patients with congenital haemostatic defects. This information is important both nationally and regionally. The National Haemophilia Register, compiled from annual returns from the regions, provides the information used in long-term planning of haemophilia treatment in the United Kingdom. " The regional register might also be valuable if a haemophiliac were to be injured in a road accident or fall ill while not carrying his special medical card.

The fact that the haemophilia centres are all in the extreme south-west of the region creates special difficulties for the co-ordinator. She is based at the transfusion centre as it is conveniently situated in the centre of the community served and is politically neutral in relation to the haemophilia centres. In other areas a haemophilia centre might prove to be a more suitable base. The setting up of well-placed associate centres also helps to improve the balance of regional care.

The reorganisation of the NHS has also created problems that can be solved by a co-ordinator. Until reorganisation only the London Hospital haemophilia centre was served by the Brentwood blood transfusion centre, while the other haemophilia centres were served by the Edgware blood transfusion centre. These three centres still receive cryoprecipitate from Edgware, though their allocations of factor VIII concentrate now come through Brentwood. Further work is required to remove these anomalies but, in the meantime, the co-ordinator is ideally placed to match supply with demand within the region.

The original co-ordinator was unable to continue the work after September 1976, but her successor took over without difficulty, as she had had experience with venepuncture on the plasmapheresis programme of the Blood Transfusion Service. If a suitable nurse were not immediately available an initial training period would be essential.

We believe that our regional co-ordinator now plays a vital role in managing patients with haemophilia, both in the hospital and in the community, and, as community-based care becomes increasingly possible, the importance of this type of appointment is likely to grow.

We thank the Haemophilia Society for making this work possible.

\section{References}

${ }^{1}$ Department of Health and Social Security, Health Circular HC(76)4. London, DHSS, 1976.

${ }^{2}$ British Medical fournal, 1977, 1, 1306

${ }^{3}$ Leslie, J, and Taylor, E, Lancet, 1975, 1, 282.

4 Aston, C, Proceedings of the $3 r d$ World Federation of Haemophilia European Congress, 1976. In press.

${ }^{5}$ Biggs, R, British fournal of Haematology, 1977, 35, 487.

(Accepted 8.7uly 1977)

ONE HUNDRED YEARS AGO Adulteration prosecutions are still being carried on with vigour in Glasgow. A confectioner was last week charged with having sold a quantity of adulterated confections. It was proved that the sweets contained chromate of lead. The accused, who pleaded that he was not aware that chromate of lead was a poisonous ingredient, was fined $£ 2$. Two milk dealers were fined similar sums for selling adulterated milk and cream. (British Medical fournal, 1877.) 